\title{
Novel foci of Dermacentor reticulatus ticks infected with Babesia canis and Babesia caballi in the Netherlands and in Belgium
}

Frans Jongejan ${ }^{1,4^{*}}$, Moniek Ringenier ${ }^{1 \dagger}$, Michael Putting ${ }^{1 \dagger}$, Laura Berger ${ }^{1}$, Stefan Burgers ${ }^{1}$, Reinier Kortekaas ${ }^{1}$, Jesse Lenssen ${ }^{1}$, Marleen van Roessel', Michiel Wijnveld ${ }^{2}$ and Maxime Madder ${ }^{3,4}$

\begin{abstract}
Background: Autochthonous populations of Dermacentor reticulatus ticks in the Netherlands were discovered after fatal cases of babesiosis occurred in resident dogs in 2004. The presence of D. reticulatus in the Netherlands has also linked with the emergence of piroplasmosis in the resident horse population. The aim of this study was to put together results of continued surveillance of field sites and hosts for this tick in the Netherlands and also in Belgium and determine their infection status for Babesia and Theileria species.

Methods: Ticks were collected from the vegetation at 11 locations between 2011 and 2013. D. reticulatus ticks were also collected from different hosts between 2007 and 2013. Ticks were screened by PCR and reverse line blot (RLB).

Results: A total of 1368 D. reticulatus ticks were collected from 4 previously known field locations and from 5 new locations in the Netherlands and from 2 sites in Belgium (one old and one new location). A total of 855 ticks collected from 8 locations in the Netherlands and 2 locations in Belgium were tested. Fourteen ticks $(1,64 \%)$ collected at 4 field locations (Dintelse Gorzen, Rozenburg, Slikken van de Heen and St. Philipsland) were positive for Babesia canis, whereas two ticks were positive for Babesia caballi, one tick in the Dintelse Gorzen in the Netherlands and one tick was found positive in De Panne in Belgium.

A further 1092 D. reticulatus ticks were collected between 2007 and 2013 from 40 dogs (132 ticks), two ticks from two humans, 51 ticks from 15 horses, two ticks from two cats, one tick from a roe deer, whereas most ticks (904) were collected from cattle $(n=25)$. Ticks were found throughout the year on dogs in nearly all provinces of the Netherlands. None of the ticks collected from these hosts were infected.

Conclusions: $D$. reticulatus is continuing its spread into novel areas. The finding that some autochthonous ticks are infected with B. canis and B. caballi poses a threat to the resident dog and horse population and justifies year-round tick control measures.
\end{abstract}

Keywords: Ticks, Dermacentor reticulatus, Netherlands, Belgium, Babesia canis, Babesia caballi

\footnotetext{
* Correspondence: F.Jongejan@uu.nl

${ }^{\dagger}$ Equal contributors

${ }^{1}$ Utrecht Centre for Tick-borne Diseases (UCTD), FAO Reference Centre for

Ticks and Tick-borne Diseases, Faculty of Veterinary Medicine, Utrecht

University, Yalelaan 1, $3584 \mathrm{CL}$, Utrecht, The Netherlands

${ }^{4}$ Department of Veterinary Tropical Diseases, Faculty of Veterinary Science,

University of Pretoria, Private Bag X04, Pretoria, Onderstepoort 0110, South

Africa

Full list of author information is available at the end of the article
} 


\section{Background}

The ornate dog tick, Dermacentor reticulatus, is a Palearctic species with a highly focal distribution pattern $[1,2]$. It occurs in isolated pockets from south-western England in the west to Central Asia until the Yenisei river basin in Siberia in the east [3-7].

D. reticulatus is an important vector of a number of protozoan tick-borne pathogens, in particular Babesia canis, the cause of canine babesiosis, and Babesia caballi and Theileria equi, which are causative agents of equine piroplasmosis [8]. Recently, Babesia microti has also been identified in questing adult $D$. reticulatus ticks, which suggests a role in the transmission of human babesiosis [9].

Moreover, D. reticulatus, collected from various locations in the Lublin region of eastern Poland, were found infected with tick-borne encephalitis (TBE) virus [10]. In addition, $D$. reticulatus collected by flagging from the vegetation in urban areas (Warsaw) as well as in national parks in the North-Eastern part of Poland were also infected with TBE virus [11].

Spotted Fever Group Rickettsiae (SFGR) causing Siberian tick typhus (Rickettsia sibirica), and human rickettsiosis (Rickettsia slovaca) have also been found in Dermacentor ticks [8]. Moreover, Rickettsia raoultii, has been detected in Dermacentor ticks by PCR in many European countries, including the Netherlands [12]. Both $R$. slovaca and $R$. raoultii are associated with human cases of tick-borne lymphadenopathy (TIBOLA) or Dermacentor-borne necrosis erythema and lymphadenopathy (DEBONEL) [13]. Interestingly, $R$. raoultii has recently been isolated and maintained in tick cell cultures initiated from eggs derived from a colony of Dutch $D$. reticulatus ticks [14].

Anaplasma phagocytophilum, causing tick-borne fever in ruminants as well as granulocytic anaplasmosis in humans, horses, dogs and cats, has recently also been detected in questing $D$. reticulatus ticks collected from the vegetation in Lithuania [15] and also in questing ticks in the Chernobyl exclusion zone [16]. Moreover, in Belgium, A. phagocytophilum was found in ticks collected from a red deer [17]. Finally, the tick has proven vector competence for Anaplasma marginale [18] and A.marginale-infected field ticks were recently reported from France [19].

Surveillance for field populations of $D$. reticulatus ticks started in 2004 in the Netherlands, when outbreaks of autochthonous canine babesiosis occurred affecting 23 dogs [20]. Nineteen animals recovered after treatment, whereas four dogs died. Adult $D$. reticulatus ticks were collected from three of these dogs. Although at the time of the outbreaks no $D$. reticulatus ticks were found in the vegetation in the walking area of these dogs, the presence of autochthonous populations of D. reticulatus ticks in the Netherlands was confirmed and reported in 2007 [12].

In addition to the emergence of babesiosis in dogs, evidence has recently been presented that equine piroplasmosis has emerged in the South-West of the Netherlands [21]. Two acute clinical Theileria equi cases and subclinical Babesia caballi infections were diagnosed in resident horses with a sero-prevalence of $1.3 \%$ among 300 horses in the South-West of the country [21]. As a result, the local $D$. reticulatus tick population has also been incriminated with autochthonous transmission of Babesia caballi and Theileria equi.

By launching the so-called "Tickbusters" survey, initially by the Royal Netherlands Society of Veterinary Medicine (KNMvD) in 2005, veterinarians throughout the Netherlands started to submit ticks collected in their practices from companion animals to the Utrecht Centre for Tick-borne Diseases (UCTD) [22]. Through interviews with persons who submitted $D$. reticulatus ticks, we were able to discover eight locations where local populations of $D$. reticulatus ticks were present in the vegetation [12]. After a decade of Tickbusters surveying, wherein more than 63,000 ticks were received, we now report additional field locations for $D$. reticulatus as well as ticks removed from dogs, horses, cattle, deer and humans between 2007 and 2013.

Similar developments have been reported in Belgium, where $D$. reticulatus tick populations were found at four distinct locations in the vegetation [5].

In this study $D$. reticulatus ticks collected from the vegetation as well as from a range of different hosts were examined for the presence of Babesia and Theileria parasites using PCR combined with reverse line blot (RLB) hybridization.

\section{Methods \\ Tick collections}

Ticks were submitted to our Reference Centre by veterinarians who removed the ticks from dogs or cats presented by pet owners in their clinics. The following data were collected: host, location, date of tick collection, engorgement status of female ticks and information whether the tick-infested pet had been outside the Netherlands during the period of tick attachment. All ticks were identified to species level with stage and sex recorded using descriptions published in a guide to the identification of ticks of domestic animal in the Mediterranean region [23]. All tick submissions were assigned a unique database number and stored in $70 \%$ ethanol until further use. When $D$. reticulatus ticks were found on an animal, the veterinarian or owner was contacted in order to find out more about the actual location where the animal may have acquired the tick. By doing so, novel field locations of resident 


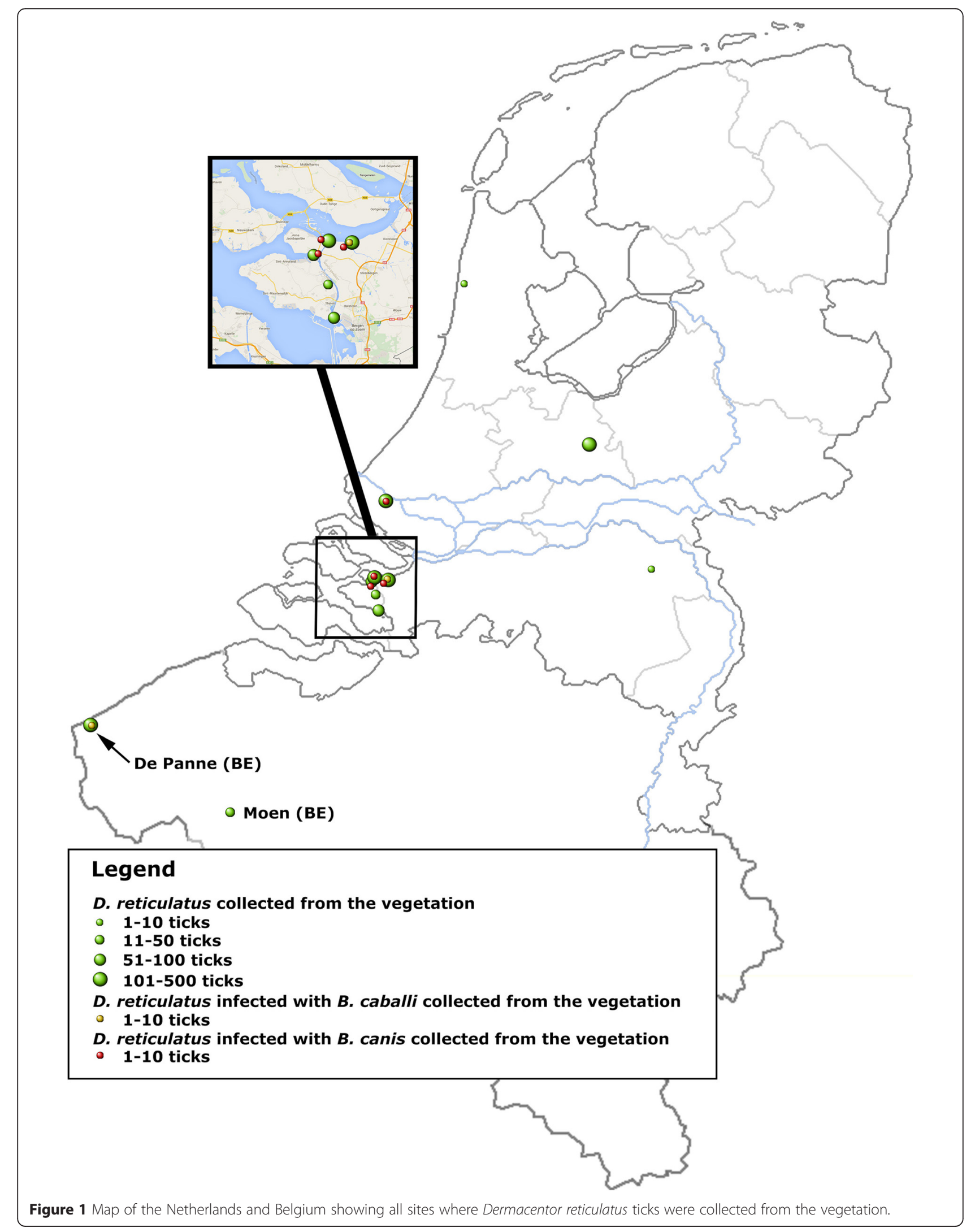


Table 1 Eleven locations in the Netherlands $(n=9)$ and Belgium $(n=2)$ where Dermacentor reticulatus ticks were collected from the vegetation

\begin{tabular}{|c|c|c|c|c|c|}
\hline Location & $\begin{array}{l}\text { Date } \\
\text { (Month-Year) }\end{array}$ & Male & Female & $\begin{array}{l}\text { Total } \\
\text { ticks per } \\
\text { collection }\end{array}$ & $\begin{array}{l}\text { Total } \\
\text { ticks per } \\
\text { location }\end{array}$ \\
\hline De Maashorst & April-12 & 0 & 2 & 2 & 2 \\
\hline \multirow[t]{4}{*}{ De Panne* } & October-11 & 97 & 111 & 208 & 287 \\
\hline & March-12 & 16 & 23 & 39 & \\
\hline & April-12 & 9 & 13 & 22 & \\
\hline & December-13 & 7 & 11 & 18 & \\
\hline \multirow[t]{5}{*}{ Dintelse Gorzen } & November-11 & 20 & 20 & 40 & 236 \\
\hline & March-12 & 51 & 59 & 110 & \\
\hline & April-12 & 5 & 7 & 12 & \\
\hline & September-12 & 1 & 5 & 6 & \\
\hline & December-13 & 25 & 43 & 68 & \\
\hline \multirow[t]{3}{*}{ Egmond aan Zee } & March-12 & 0 & 1 & 1 & 4 \\
\hline & October-12 & 1 & 0 & 1 & \\
\hline & December-13 & 1 & 1 & 2 & \\
\hline \multirow{3}{*}{$\begin{array}{l}\text { Utrechtse } \\
\text { Heuvelrug }\end{array}$} & March-12 & 18 & 35 & 53 & 208 \\
\hline & April-12 & 52 & 99 & 151 & \\
\hline & October-12 & 3 & 1 & 4 & \\
\hline Moen* & April-12 & 10 & 13 & 23 & 23 \\
\hline \multirow[t]{2}{*}{ Oud-Vossemeer } & September-12 & 9 & 2 & 11 & 29 \\
\hline & December-13 & 5 & 13 & 18 & \\
\hline \multirow[t]{6}{*}{ Rozenburg } & January-11 & 19 & 33 & 52 & 220 \\
\hline & February-11 & 27 & 38 & 65 & \\
\hline & March-11 & 8 & 11 & 19 & \\
\hline & September-11 & 20 & 20 & 40 & \\
\hline & March-12 & 0 & 1 & 1 & \\
\hline & December-13 & 21 & 22 & 43 & \\
\hline \multirow{4}{*}{$\begin{array}{l}\text { Slikken van de } \\
\text { Heen }\end{array}$} & March-12 & 40 & 49 & 89 & 228 \\
\hline & April-12 & 25 & 30 & 55 & \\
\hline & September-12 & 20 & 16 & 36 & \\
\hline & November-13 & 20 & 28 & 48 & \\
\hline \multirow[t]{2}{*}{ St. Philipsland } & March-12 & 23 & 32 & 55 & 63 \\
\hline & November-13 & 2 & 6 & 8 & \\
\hline \multirow[t]{3}{*}{ Tholen } & September-12 & 11 & 6 & 17 & 68 \\
\hline & October-12 & 0 & 11 & 11 & \\
\hline & November-13 & 17 & 23 & 40 & \\
\hline Total & & 583 & 785 & 1368 & \\
\hline
\end{tabular}

*These locations are situated in Belgium.

populations of $D$. reticulatus were revealed. These areas were subsequently monitored for the presence of ticks by flagging, which is considered more effective than dragging for collecting adult ticks [24]. Additional D. reticulatus ticks were received that had been collected from horses, cats, cattle, roe deer and humans. Efforts were made to track the ticks to where they had been picked up by these hosts in order to locate additional field sites.

\section{DNA extraction, PCR amplification and reverse line blot hybridization}

DNA was extracted from individual ticks using the NucleoSpin ${ }^{\circ}$ Tissue Kit (Macherey-Nagel, Germany). Ticks were disrupted in lysis buffer using the TissueLyser LT (Qiagen, The Netherlands) with $5 \mathrm{~mm}$ stainless steel beads according to the instructions of the manufacturer. All genomic DNA was stored at $-20^{\circ} \mathrm{C}$ until used for PCR amplification. Babesia/Theileria PCR was performed using primers RLB-F2 (5' -GACACAGGGAGGTAGTGACAAG-3') and RLB-R2 (biotin-5' -CTAAGAATTTCACC TCTGACAGT-3') to amplify a fragment of 460-540 bp from the 18SrRNA gene spanning the $\mathrm{V} 4$ region [25]. Reactions were performed in $25 \mu \mathrm{l}$ volumes in PCR Buffer, $200 \mu \mathrm{M}$ of dNTP, $400 \mu \mathrm{M}$ of each primer, $0.125 \mu \mathrm{l}$ of Phire Hot Start II Polymerase (Fisher Scientific, The Netherlands) and $2.5 \mu \mathrm{l}$ of genomic DNA. Further PCR conditions based on a touch-down assay were recently described by [26]. Positive and negative controls were included in each run.

Reverse line blot (RLB) hybridization was performed according to methods originally published by Gubbels et al. (1999) [27], modified by Nijhof et al. (2003) [28] and updated by Giangaspero et al. (2015) [26]. In brief, oligonucleotide probes containing an N-terminal C6 amino linker (Eurogentec, The Netherlands) were covalently linked to the RLB membrane (Biodyne C blotting membrane; Pall Biosupport, Ann Arbor, MI, USA) using the following procedure. Membranes were activated in a freshly prepared 10-ml solution of 16\% 1-ethyl 3-(3-dimethylaminopropyl) carbodiimide $\mathrm{HCl}$ (Sigma, St. Louis, MO), rinsed, and then placed in an MN45 miniblotter (Immunetics, Cambridge, MA) and residual liquid aspirated. Oligonucleotide probes ( $400 \mathrm{pmol} / 150 \mu \mathrm{l}$ in $500 \mathrm{mM}$ NaHCO3 solution ( $\mathrm{pH}$ 8.4) were linked to the membrane by loading into the lanes of the miniblotter. After aspiration of the oligonucleotide probe solutions, the membrane was washed and inactivated in a $100 \mathrm{ml}$ freshly prepared $100 \mathrm{mM}$ $\mathrm{NaOH}$ solution at room temperature under gentle shaking. The RLB membrane was hybridized with the PCR products and further developed as described elsewhere [27].

\section{Results}

\section{Tick collections}

D. reticulatus ticks were collected by flagging the vegetation in four previously known field sites and in five novel locations in the Netherlands and from two sites in Belgium (one known and one novel location) (Figure 1). 


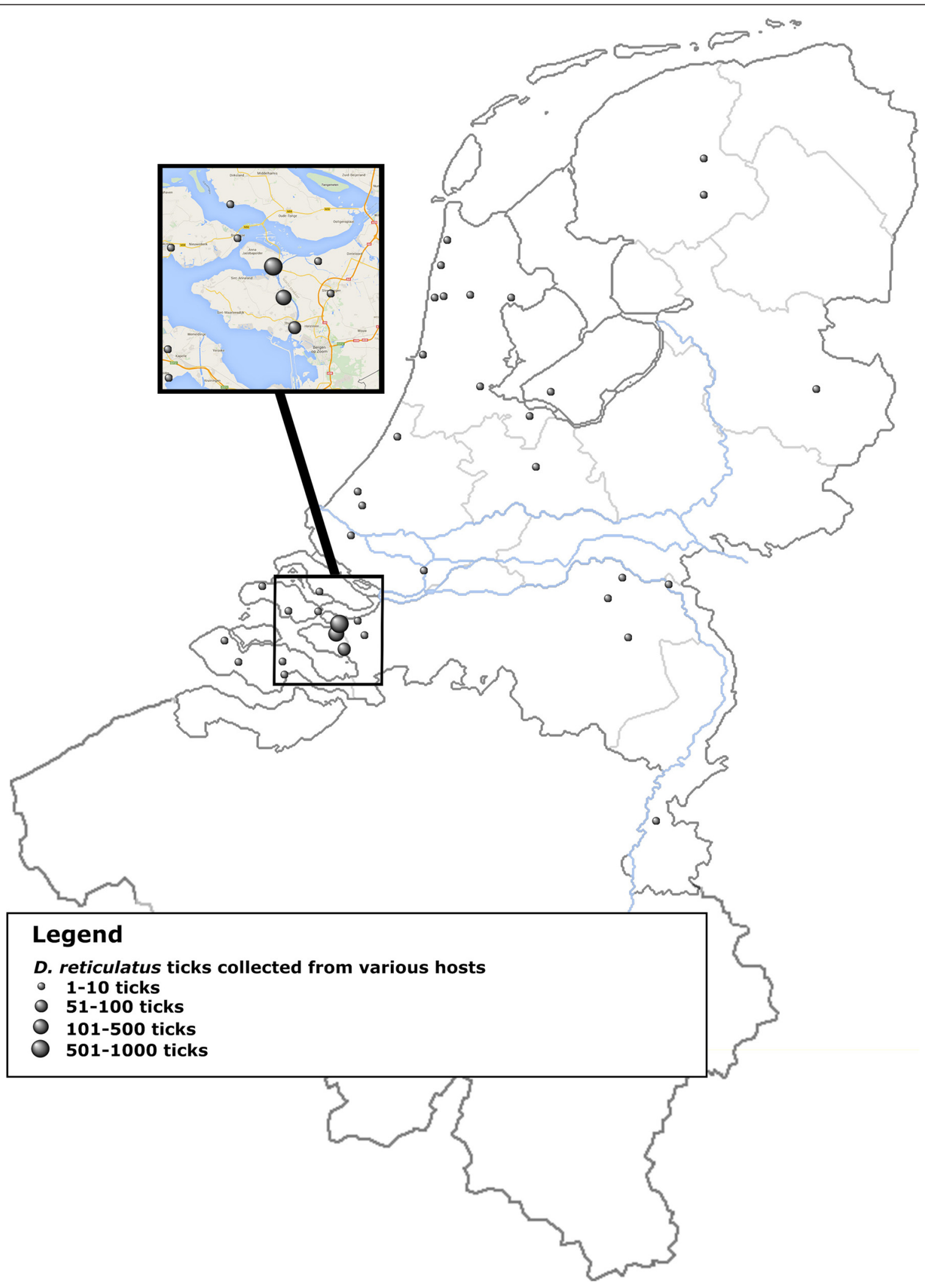

Figure 2 Map of the Netherlands and Belgium showing all sites where Dermacentor reticulatus ticks were collected from a range of different hosts. 
A total of 1368 (583 males and 785 female ticks) were collected in 11 sites from 2011 to 2013 (Table 1).

From various hosts, a total of 1092 ticks (681 males and 411 females) were collected between 2007 and 2013: 132 ticks from 40 dogs, two ticks recovered from two humans, 51 ticks collected from 15 horses, two ticks from two cats, one tick from a roe deer and 904 ticks were collected from cattle $(n=25)$ (Figure 2; Table 2).

\section{Pathogen detection}

A total of 855 ticks collected from 8 locations in the Netherlands and 2 locations in Belgium were screened by PCR/RLB for the presence of Babesia and Theileria species (Table 3). Fourteen ticks (1.64\%) collected in 4 different field locations (Dintelse Gorzen, Rozenburg, Slikken van de Heen and St. Philipsland) were positive for $B$. canis, whereas two ticks were positive for $B$. caballi; one was found in the vegetation in the Dintelse Gorzen in the Netherlands and one positive tick found in de Panne located in Belgium at the coast near the French border (Figure 1).

None of the ticks collected from dogs, cats, horses, cattle or humans were infected with any known Babesia or Theileria species.

\section{Discussion}

Significant numbers of adult $D$. reticulatus ticks $(\mathrm{n}=1368)$ were collected at nine locations in the Netherlands and at two locations in Belgium between 2011 and 2013 in autumn to early spring (September-April), but not in summer (Table 1). Most locations were found through the ongoing "Tickbusters" survey [22], although three locations (De Panne, Utrechtse Heuvelrug and Egmond aan Zee) were posted on flora and fauna observation data collection sites (www.waarneming.nl and www.waarnemingen.be). $D$. reticulatus was found to be abundant in freshwater tidal marches, such as Dintelse Gorzen $(\mathrm{n}=236)$, OudVossemeer $(n=29)$, Slikken van de Heen $(n=228)$, St. Philipsland $(n=63)$ and Tholen $(n=68)$, all situated in close proximity to waterways in the south-western part of the Netherlands (Figure 1). These locations are characterized by a high soil moisture and shelter against desiccation, which makes them suitable for tick survival, whereas the presence of populations of cattle, sheep, horses and even roe deer provide ample opportunity for adult ticks to feed on. Although no larvae or nymphs of this tick were collected, it can be assumed that immature ticks are being maintained in these locations on rodents during the summer months as is known to occur in other areas, e.g. France or Poland [7,29].

Several locations (Dintelse Gorzen, Slikken van de Heen and St. Philipsland) had been visited before and appear to sustain permanent populations of $D$. reticulatus since 2005 [12]. New locations within the same area in the South-West, and of similar ecological texture, are reported here (Oud-Vossemeer and Tholen) (Figure 1; Table 1).

Other locations where lower numbers of $D$. reticulatus had been reported previously include a deciduous forest (De Maashorst) $(\mathrm{n}=12)$ and a dune valley (St. Maartenszee) $(\mathrm{n}=11)$ [12]. In the current survey, only 2 ticks were found at De Maashorst, whereas 4 ticks were collected at Egmond aan Zee, a location near St. Maartenszee, both situated in a typical dune landscape with similar ecological characteristics near the cost in the north-western part of the country. Although deciduous forests and dune valleys appear to be less favourable areas for $D$. reticulatus to survive, a large number of ticks $(n=208)$ were found in a novel location situated in a deciduous forest (Utrechtse Heuvelrug) in the central part of the Netherlands. This is a recreational area characterized by a fragmented habitat consisting of deciduous forest, small lakes and heathland sustaining flocks of sheep. Moreover, whereas few ticks were found in the dune valleys in the Netherlands (Egmond aan Zee), large numbers of ticks $(n=287)$ were collected in Belgium in De Panne, a conservation area consisting of dune valleys close to the sea near the French border (Figure 1; Table 1). In this novel site in Belgium, ticks were most frequently found in high dry grass alongside a fence separating the dunes from fields where cattle and horses were grazing.

In the Netherlands, one further novel location was discovered near the city of Rotterdam (Rozenburg) (Figure 1) where a total of 220 ticks were collected and distributed over three different seasons (2011-2013). Rozenburg is characterized by a moist dune-like landscape, where cattle and horses graze freely and access to the public is made through dedicated fences.

In Belgium, Moen, a natural reserve of about 26 hectares along a canal accessible for recreational purposes, was revisited in 2012 and only 23 ticks were collected. $D$. reticulatus had been previously collected from the vegetation in Moen as well as in 3 other localities in Belgium as previously reported [5].

More than $60 \%$ of the ticks collected at the various field locations were screened by PCR/RLB (Table 3). Fourteen ticks $(1.64 \%)$ collected in four locations (Dintelse Gorzen, Rozenburg, Slikken van de Heen and St. Philipsland) were positive for $B$. canis. Furthermore, two ticks were positive for B. caballi, one was found in the vegetation in the Dintelse Gorzen in the Netherlands and one tick was found in de Panne in Belgium. These are the first findings of indigenous field ticks infected with $B$. canis and $B$. caballi in the Netherlands and in Belgium, whereas ticks examined in previous surveys were negative for both parasites $[5,12,30]$.

Dogs travelling to and from endemic areas in Europe have introduced infected $D$. reticulatus ticks. Once, introduced, $D$. reticulatus can sustain the Babesia infection for 
Table 2 Dermacentor reticulatus ticks collected from various hosts in the Netherlands

\begin{tabular}{|c|c|c|c|c|}
\hline Location & Date (Month-Year) & Host (number) & Province & Number of ticks (male/female) \\
\hline \multirow[t]{2}{*}{ Steenbergen } & January-07 & Human & Drenthe & $1(1 /-)$ \\
\hline & October-11 & Dog, horse & Drenthe & $2(1 / 1)$ \\
\hline Almere-stad & May-08 & Dog & Flevoland & $1(-/ 1)$ \\
\hline Drachten & July-08 & Dog & Friesland & $1(-/ 1)$ \\
\hline Gorredijk & September-10 & Dog & Friesland & $1(-/ 1)$ \\
\hline Geleen & June-09 & Dog & Limburg & $1(-/ 1)$ \\
\hline Middelaar & August-10 & Dog & Limburg & $1(1 /-)$ \\
\hline De Maashorst & May-09 & Horses (2) & Noord-Brabant & $2(-/ 2)$ \\
\hline \multirow[t]{2}{*}{ Dintelse Gorzen } & November-08 & Horse & Noord-Brabant & $1(1 /-)$ \\
\hline & May-09 & Roedeer & & $1(-/ 1)$ \\
\hline Gemert & September-08 & Dog & Noord-Brabant & $1(1 /-)$ \\
\hline Reek & May-08 & Dog & Noord-Brabant & $1(-/ 1)$ \\
\hline Amsterdam & September-09 & Dog & Noord-Holland & $1(1 /-)$ \\
\hline Bergen & December-13 & Human & Noord-Holland & $1(-/ 1)$ \\
\hline Bussum & May-09 & Dog & Noord-Holland & $4(-/ 4)$ \\
\hline Egmond aan den Hoef & September-07 & Dog & Noord-Holland & $1(1 /-)$ \\
\hline \multirow[t]{4}{*}{ Egmond aan Zee } & October-12 & Dog & Noord-Holland & $1(1 /-)$ \\
\hline & April-13 & Dog & & $1(1 /-)$ \\
\hline & October-13 & Dog & & $1(1 /-)$ \\
\hline & December-13 & Dog & & $1(1 /-)$ \\
\hline Heerhugowaard & November-09 & Dog & Noord-Holland & $1(-/ 1)$ \\
\hline Hoorn & September-10 & Dog & Noord-Holland & $1(-/ 1)$ \\
\hline Sint Maartenszee & February-09 & $\operatorname{Dog}(2)$ & Noord-Holland & $6(-/ 6)$ \\
\hline Wijk aan Zee & January-13 & Dog & Noord-Holland & $1(1 /-)$ \\
\hline Almelo & April-07 & Dog & Overijssel & $1(-/ 1)$ \\
\hline De Bilt & March-12 & Dog & Utrecht & $1(-/ 1)$ \\
\hline Bruinisse & February-07 & Dogs (2) & Zeeland & $2(1 / 1)$ \\
\hline Grevelingen & October-13 & Dog & Zeeland & $1(1 /-)$ \\
\hline 's Heer Arendskerke & March-07 & Dog & Zeeland & $1(1 /-)$ \\
\hline Hoedekenskerke & May-2012 & Dog & Zeeland & $1(-/ 1)$ \\
\hline Middelburg & September-07 & Dog & Zeeland & $1(1 /-)$ \\
\hline \multirow[t]{3}{*}{ Oud-Vossemeer } & November-09 & Cattle & Zeeland & $121(40 / 81)$ \\
\hline & September-12 & Horse & & $5(1 / 4)$ \\
\hline & October-12 & Horse & & $31(18 / 13)$ \\
\hline Renesse & May-10 & Horse & Zeeland & $7(-/ 7)$ \\
\hline Serooskerke & March-12 & Horse & Zeeland & $3(3 /-)$ \\
\hline \multirow[t]{4}{*}{ Tholen } & September-12 & Dogs (2) & Zeeland & $5(3 / 2)$ \\
\hline & October-12 & Dog & & $3(2 / 1)$ \\
\hline & January-13 & Dogs (3) & & $61(20 / 41)$ \\
\hline & April-13 & Dogs (3) & & $24(7 / 17)$ \\
\hline \multirow[t]{2}{*}{ Zierikzee } & April-07 & Dog & Zeeland & $1(1 /-)$ \\
\hline & September-10 & Cat & & $1(1 /-)$ \\
\hline Den Haag & March-10 & Dog & Zuid-Holland & $1(-/ 1)$ \\
\hline Noordwijk & September-09 & Dog & Zuid-Holland & $1(-/ 1)$ \\
\hline
\end{tabular}


Table 2 Dermacentor reticulatus ticks collected from various hosts in the Netherlands (Continued)

\begin{tabular}{|c|c|c|c|c|}
\hline Rijswijk & March-09 & Cat & Zuid-Holland & $1(1 /-)$ \\
\hline Rozenburg & February-11 & Dog & Zuid-Holland & $1(-/ 1)$ \\
\hline Zwijndrecht & November-12 & Dog & Zuid-Holland & $1(-/ 1)$ \\
\hline \multirow[t]{5}{*}{ Sint Philipsland } & September-08 & Cattle (25) & Zeeland & $9(5 / 4)$ \\
\hline & November-08 & & & $297(191 / 106)$ \\
\hline & November-09 & & & $128(74 / 54)$ \\
\hline & November -11 & & & $40(1 / 39)$ \\
\hline & November -12 & & & $309(297 / 12)$ \\
\hline Total & & & & $1092(681 / 411)$ \\
\hline
\end{tabular}

several generations. This can lead to the occurrence of autochthonous cases as previously reported in the Netherlands [20,31] and Belgium [32] and more recently also in Norway [33] and Switzerland [34]. The chance however for dogs to pick-up infected $D$. reticulatus ticks from infected field sites remains low because of the low infection rate. This may explain why additional clinical cases have not (yet) been reported in the Netherlands or in Belgium. However, infection rates of B. canis in $D$. reticulatus ticks vary from $0 \%$ in studies conducted for instance in Germany [35] to $2.3 \%(n=1205)$ in south-western Slovakia to as high as $14.7 \%(n=327)$ in eastern Slovakia [4].

The finding of $B$. caballi-infected ticks at the Dintelse Gorzen in the Netherlands and also in the Panne in Belgium provides additional evidence that equine piroplasmosis is transmitted by indigenous $D$. reticulatus ticks. Cases of B. caballi in horses reported in a survey conducted in the area in the south-western part of the Netherlands had been previously attributed to the presence of $D$. reticulatus [21]. Moreover, D. reticulatus ticks $(n=51)$ were found on horses $(n=15)$, which may have

Table 3 Pathogens detected in Dermacentor reticulatus ticks from the vegetation by PCR/RLB

\begin{tabular}{llll}
\hline Location & Total tested & B. caballi & B. canis \\
\hline De Maashorst & Not done & - & - \\
De Panne (BE) & 266 & 1 & Neg \\
Dintelse Gorzen & 110 & 1 & 1 \\
Egmond aan Zee & 3 & Neg & Neg \\
Utrechtse Heuvelrug & 40 & Neg & Neg \\
Moen (BE) & 23 & Neg & Neg \\
Oud-Vossemeer & 27 & Neg & Neg \\
Rozenburg & 80 & Neg & 10 \\
Slikken van de Heen & 80 & Neg & 2 \\
St. Philipsland & 48 & Neg & 1 \\
Tholen & 56 & Neg & Neg \\
Total & $\mathbf{8 5 5}$ & $\mathbf{2 ( 0 , 2 3 \% )}$ & $\mathbf{1 4 ( 1 , 6 4 \% )}$ \\
\hline
\end{tabular}

acquired them in or around two known locations (De Maashorst and Oud-Vossemeer) and in three novel locations (Table 2). Like B. canis, B. caballi can be maintained in several generations of $D$. reticulatus ticks. Although clinical cases have not been reported in Belgium, this does not mean that they have not occurred since there is no notification process in place. Treatment of clinical cases is probably the best approach, since prevention through tick control is limited because no product has been registered on the local markets.

Furthermore, D. reticulatus ticks $(\mathrm{n}=132)$ were collected from 40 different dogs examined at 28 different locations throughout the Netherlands (Figure 2; Table 2). Importantly, dogs apparently did pick up ticks near or at locations known to harbour resident tick populations in the vegetation, demonstrated by the clustering around Egmond aan Zee, Oud-Vossemeer, Tholen and Rozenburg (Figure 1). Interestingly, ticks were found on dogs in all provinces in the Netherlands, except in Groningen and were found on dogs throughout the year, although very few ticks were seen during the summer months (Table 2; Figure 2). Often, ticks were engorged which demonstrates that dogs (and horses) contribute to the further dissemination of this tick. As a result, there were ticks found on hosts which could not be linked to any know field site, which indicates that most likely additional field locations in the Netherlands are infested with $D$. reticulatus. Adult activity of this tick throughout the year justifies yearround prophylaxis preferably using products that have been tested with respect to their ability to prevent transmission of B. canis [36-38].

A common denominator in all previous and novel locations is the presence of free-ranging populations of small as well as large ruminants. Also, most sites are located inside nature conservation areas with limited access to the public. However, most ticks were picked-up in patches alongside fences separating dog walking or horse trails from pastures and fields where ruminants are grazing. Ticks were also collected from animals grazing in some of the locations were $D$. reticulatus had 
been identified. Cattle in St. Philipsland, which were on pasture between April and November each year and grazing in typical freshwater tidal marches were found infested with large numbers of adult $D$. reticulatus ticks ( $\mathrm{n}=904$ collected at four occasions between September 2008 and November 2012) (Table 2). This clearly demonstrates that this particular location provides ideal environmental conditions for permanent residency of $D$. reticulatus in the Netherlands.

The finding of a single tick on a roe deer in one of the know locations (Dintelse Gorzen) indicated that further surveillance for ticks on wildlife is required in order to determine the relative role of deer and other wildlife species in the dissemination of $D$. reticulatus in the Netherlands and in Belgium, where large wildlife populations are present. Finally, two ticks recovered from humans indicate that identification of ticks on humans is meaningful and could lead to zoonotic pathogen identification. Our findings are in agreement with the known host range for three-host $D$. reticulatus ticks, with immature ticks feeding on rodents and adult ticks feeding on a broad range of domestic and wild hosts, e.g. dogs, horses, cattle, sheep, deer, and swine) $[2,7,23]$.

Clearly, changes in ecosystem management with consequent increased wildlife host abundance combined with grazing of large domestic ruminants in nature reserves has created favourable conditions to sustain $D$. reticulatus populations once introduced [39]. Although usually some I. ricinus ticks were also present on the vegetation or on hosts (cattle), D. reticulatus outnumbered I. ricinus at all locations that were visited (unpublished observations). Interesting, recent data show that $D$. reticulatus is the predominant tick species in the vegetation in selected areas of Slovakia [40]. However, widespread dissemination of $D$. reticulatus, into, for instance, deciduous forests, where $I$. ricinus predominates, is unlikely. In addition to the ecological requirements that need to be in place for the tick to survive, $D$. reticulatus nymphs do not feed as frequently as I. ricinus nymphs on birds, hence its horizontal dispersion is limited [23].

Finally, continued longitudinal surveillance is recommended including a broad molecular screening to encompass not only the confirmed Babesia and Theileria species, but also Rickettsia and Anaplasma species, and TBE virus since all these pathogens have been found in questing $D$. reticulatus ticks found elsewhere in Europe $[11,13,15,19]$.

\section{Conclusion}

This study showed that $D$. reticulatus ticks are slowly but steadily spreading within in the Netherlands and Belgium. Adult activity of this tick on dogs throughout the year justifies year-round prophylaxis. Continued surveillance is required to monitor the distribution of
D. reticulatus and associated tick-borne diseases in the resident dog and horse population in the Netherlands and in Belgium.

\section{Competing interests}

The authors declare that they have no competing interests.

\section{Authors' contributions}

MR and MP contributed equally to the work, which was focussed on tick identification, DNA extraction and molecular analysis (RLB). MP and RK conducted most of the field surveys. LB and MW designed the molecular survey (PCR/RLB) and analysed the data. SB designed the graphics (Figures 1 and 2), whereas $J$ coordinated the Tickbusters survey and the tick database. MM contributed novel distribution data from Belgium. FJ designed the study and wrote the paper. All authors have read and approved the final version of the paper.

\section{Acknowledgements}

Prof. Frederic Beugnet and Dr. Fabien Danlois of Merial are thanked for their continued interest and financial support for this study. We gratefully acknowledge all veterinarians who submitted ticks and additional information to our Reference Centre in the context of the ongoing Tickbusters campaign. Special thanks are due to Peter Nieuwenhuizen from St. Philipsland for his collaboration and access to his cattle and pastures over several years of investigations. Finally, John Bouwmans is thanked for alerting us to the presence of $D$. reticulatus ticks in the province of Utrecht.

\section{Author details}

${ }^{1}$ Utrecht Centre for Tick-borne Diseases (UCTD), FAO Reference Centre for Ticks and Tick-borne Diseases, Faculty of Veterinary Medicine, Utrecht University, Yalelaan 1, $3584 \mathrm{CL}$, Utrecht, The Netherlands. ${ }^{2}$ Current address: Institute for Hygiene and Applied Immunology, Center for Pathophysiology, Infectiology and Immunology, Medical University of Vienna, Kinderspitalgasse 15, 1090 Vienna, Austria. ${ }^{3}$ Unit of Veterinary Entomology, Department of Biomedical Sciences, Institute of Tropical Medicine, Nationalestraat 155, B2000 Antwerp, Belgium. ${ }^{4}$ Department of Veterinary Tropical Diseases, Faculty of Veterinary Science, University of Pretoria, Private Bag X04, Pretoria, Onderstepoort 0110, South Africa.

Received: 5 March 2015 Accepted: 3 April 2015

Published online: 17 April 2015

\section{References}

1. Gray JS, Dautel H, Estrada-Peña A, Kahl O, Lindgren E. Effects of climate change on ticks and tick-borne diseases in europe. Interdiscip Perspect Infect Dis. 2009;2009:1-12.

2. Estrada-Peña A, Farkas R, Jaenson TGT, Koenen F, Madder M, Pascucci I, et al. Association of environmental traits with the geographic ranges of ticks (Acari: Ixodidae) of medical and veterinary importance in the western Palearctic. A digital data set. Exp Appl Acarol. 2013;59:351-66.

3. Dautel H, Dippel C, Oehme R, Hartelt K, Schettler E. Evidence for an increased geographical distribution of Dermacentor reticulatus in Germany and detection of Rickettsia sp. RpA4. Int J Med Microbiol. 2006;296(Supplement 1):149-56.

4. Kubelová M, Tkadlec E, Bednář M, Roubalová E, Široký P. West-to-east differences of Babesia canis canis prevalence in Dermacentor reticulatus ticks in Slovakia. Vet Parasitol. 2011;180:191-6.

5. Cochez C, Lempereur L, Madder M, Claerebout E, Simons L, De Wilde N, et al. Foci report on indigenous Dermacentor reticulatus populations in Belgium and a preliminary study of associated babesiosis pathogens. Med Vet Entomol. 2012;26:355-8.

6. Rubel F, Brugger K, Monazahian M, Habedank B, Dautel H, Leverenz S, et al. The first German map of georeferenced ixodid tick locations. Parasit Vectors. 2014;7:477.

7. Karbowiak $\mathrm{G}$. The occurrence of the Dermacentor reticulatus tick - its expansion to new areas and possible causes. Ann Parasitol. 2014;60:37-47.

8. Jongejan F, Uilenberg G. The global importance of ticks. Parasitology. 2004;129:S3-S14.

9. Wójcik-Fatla A, Bartosik K, Buczek A, Dutkiewicz J. Babesia microti in Adult Dermacentor reticulatus Ticks from Eastern Poland. Vector-Borne Zoonotic Dis. 2012;12:841-3. 
10. Wójcik-Fatla A, Cisak E, Zajac V, Zwoliński J, Dutkiewicz J. Prevalence of tick-borne encephalitis virus in Ixodes ricinus and Dermacentor reticulatus ticks collected from the Lublin region (eastern Poland). Ticks Tick Borne Dis. 2011;2:16-9.

11. Biernat B, Karbowiak G, Werszko J, Stańczak J. Prevalence of tick-borne encephalitis virus (TBEV) RNA in Dermacentor reticulatus ticks from natural and urban environment, Poland. Exp Appl Acarol. 2014;64:543-51.

12. Nijhof AM, Bodaan C, Postigo M, Nieuwenhuijs H, Opsteegh M, Franssen L, et al. Ticks and associated pathogens collected from domestic animals in the Netherlands. Vector Borne Zoonotic Dis. 2007;7:585-95.

13. Parola P, Rovery C, Rolain JM, Brouqui P, Davoust B, Raoult D. Rickettsia slovaca and R. raoultii in Tick-borne Rickettsioses. Emerg Infect Dis. 2009:15:1105-8

14. Alberdi MP, Nijhof AM, Jongejan F, Bell-Sakyi L. Tick cell culture isolation and growth of Rickettsia raoultii from Dutch Dermacentor reticulatus ticks. Ticks Tick Borne Dis. 2012;3:349-54.

15. Paulauskas A, Radzijevskaja J, Rosef O. Molecular detection and characterization of Anaplasma phagocytophilum strains. Comp Immunol Microbiol Infect Dis. 2012;35:187-95.

16. Karbowiak G, Vichová B, Slivinska K, Werszko J, Didyk J, Pet'ko B, et al. The infection of questing Dermacentor reticulatus ticks with Babesia canis and Anaplasma phagocytophilum in the Chernobyl exclusion zone. Vet Parasitol. 2014:204:372-5.

17. Wirtgen M, Nahayo A, Linden A, Garigliany M, Desmecht D. Detection of Anaplasma phagocytophilum in Dermacentor reticulatus ticks. Vet Rec. 2011;168:195.

18. Zivkovic Z, Nijhof AM, de la Fuente J, Kocan KM, Jongejan F. Experimental transmission of Anaplasma marginale by male Dermacentor reticulatus. BMC Vet Res. 2007:3:32

19. Bonnet S, de la Fuente J, Nicollet P, Liu X, Madani N, Blanchard B, et al. Prevalence of tick-borne pathogens in adult dermacentor spp. ticks from nine collection sites in France. Vector Borne Zoonotic Dis. 2013;13:226-36.

20. Matjila TP, Nijhof AM, Taoufik A, Houwers D, Teske E, Penzhorn BL, et al. Autochthonous canine babesiosis in The Netherlands. Vet Parasitol. 2005;131:23-9.

21. Butler CM, van Oldruitenborgh-Oosterbaan MM S, Stout TAE, van der Kolk $J H$, Van Den WL, Nielen M, et al. Prevalence of the causative agents of equine piroplasmosis in the South West of The Netherlands and the identification of two autochthonous clinical Theileria equi infections. Vet J. 2012;193:381-5.

22. Lenssen J, Wijnveld M, Conijn A, Luijten A, Jongejan F. The "tick busters" survey. Tijdschr Diergeneeskd. 2011;136:508-11

23. Estrada-peña A, Bouattour A, Camicas J-L, Walker AR: Ticks of Domestic Animals in the Mediterranean Region: A Guide to Identification of Species. 2004.

24. Dantas-Torres F, Lia RP, Capelli G, Otranto D. Efficiency of flagging and dragging for tick collection. Exp Appl Acarol. 2013;61:119-27.

25. Georges K, Loria GR, Riili S, Greco A, Caracappa S, Jongejan F, et al. Detection of haemoparasites in cattle by reverse line blot hybridisation with a note on the distribution of ticks in Sicily. Vet Parasitol. 2001;99:273-86.

26. Giangaspero A, Marangi M, Papini R, Paoletti B, Wijnveld M, Jongejan F. Theileria sp. OT3 and other tick-borne pathogens in sheep and ticks in Italy: Molecular characterization and phylogeny. Ticks Tick Borne Dis. 2015;6:75-83.

27. Gubbels JM, De Vos AP, Van der Weide M, Viseras J, Schouls LM, De Vries E, et al. Simultaneous detection of bovine Theileria and Babesia species by reverse line blot hybridization. J Clin Microbiol. 1999:37:1782-9.

28. Nijhof AM, Penzhorn BL, Lynen G, Mollel JO, Morkel P, Bekker CPJ, et al. Babesia bicornis sp. nov. and Theileria bicornis sp. nov.: Tick-Borne Parasites Associated with Mortality in the Black Rhinoceros (Diceros bicornis). J Clin Microbiol. 2003:41(5):2249-54

29. Martinod S, Gilot B. Epidemiology of canine babesiosis in relation to the activity of Dermacentor reticulatus in southern Jura (France). Exp Appl Acarol. 1991;11:215-22

30. Claerebout E, Losson B, Cochez C, Casaert S, Dalemans A-C, De Cat A, et al Ticks and associated pathogens collected from dogs and cats in Belgium. Parasit Vectors. 2013;6:183.

31. Uilenberg G, Top PDJ, Arends PJ, Kool PJ, Van Dijk JE, Van Schieveen PBE, et al. Autochtone babesiose bij de hond in Nederland? Tijdschr Diergeneesk. 1985;110:93-8.
32. Losson B, Mollet J, Avez F, Malaise F, Mignon B. Description de trois cas autochtones de babesiose canine (Babesia canis) en Belgique. Ann Med Vet. 1999;143:119-24

33. Øines $\varnothing$, Storli K, Brun-Hansen H. First case of babesiosis caused by Babesia canis canis in a dog from Norway. Vet Parasitol. 2010;171:350-3.

34. Schaarschmidt D, Gilli U, Gottstein B, Marreros N, Kuhnert P, Daeppen JA, et al. Questing Dermacentor reticulatus harbouring Babesia canis DNA associated with outbreaks of canine babesiosis in the Swiss Midlands. Ticks Tick Borne Dis. 2013;4:334-40.

35. Schreiber C, Krücken J, Beck S, Maaz D, Pachnicke S, Krieger K, et al. Pathogens in ticks collected from dogs in Berlin/Brandenburg. Germany Parasit Vectors. 2014;7:535.

36. Jongejan F, Fourie JJ, Chester ST, Manavella C, Mallouk Y, Pollmeier MG, et al. The prevention of transmission of Babesia canis canis by Dermacentor reticulatus ticks to dogs using a novel combination of fipronil, amitraz and (S)-methoprene. Vet Parasitol. 2011;179:343-50.

37. Fourie JJ, Stanneck D, Jongejan F. Prevention of transmission of Babesia canis by Dermacentor reticulatus ticks to dogs treated with an imidacloprid/flumethrin collar. Vet Parasitol. 2013;192:273-8.

38. Beugnet $F$, Halos L, Larsen D, Labuschagné $M$, Erasmus $H$, Fourie J. The ability of an oral formulation of afoxolaner to block the transmission of Babesia canis by Dermacentor reticulatus ticks to dogs. Parasit Vectors. 2014:283.

39. Beugnet F, Marié JL. Emerging arthropod-borne diseases of companion animals in Europe. Vet Parasitol. 2009;163:298-305.

40. Švehlová A, Berthová L, Sallay B, Boldiš V, Sparagano OAE, Špitalská E, et al. Sympatric occurrence of Ixodes ricinus, Dermacentor reticulatus and Haemaphysalis concinna ticks and Rickettsia and Babesia species in Slovakia. Ticks Tick Borne Dis. 2014;5:600-5.

\section{Submit your next manuscript to BioMed Central and take full advantage of:}

- Convenient online submission

- Thorough peer review

- No space constraints or color figure charges

- Immediate publication on acceptance

- Inclusion in PubMed, CAS, Scopus and Google Scholar

- Research which is freely available for redistribution

Submit your manuscript at www.biomedcentral.com/submit 